\title{
20 \\ Matting Impressions from Lo Gach: Materiality at Floor Level
}

\author{
Judith Cameron
}

In Southeast Asia, organic materials do not generally survive in the archaeological record, especially fibre-based artefacts. In this paper, I report on some rare, well-preserved impressions of floor matting discovered during the 2014 excavations at the site of Lo Gach, Long An Province, southern Vietnam, dated to ca. $2750 \mathrm{cal}$. BP. The impressions not only provide useful insights into weaving technology in the past, they also indicate that the techniques utilised more than 2,500 years ago to produce mats and winnowing trays have endured until the present day.

\section{Introduction}

Since fibres are amongst the most fragile of all organic materials, the absence of direct archaeological evidence of matting has obscured the fundamental role that this class of artefact played in prehistoric societies, not only in Southeast Asia but almost everywhere. Matting is a fibre-based artefact, intermediate between basketry and textiles woven on looms. Before the invention of furniture, all interaction took place at floor level and considerable economic expenditure would have been utilised in manufacturing mats for domestic consumption and trade. Throughout Southeast Asia, floor mats continue to provide comfort when sitting and sleeping, as well as defining space. This class of artefact also has an integral role in agricultural societies where it is used when processing and storing farm and forest products, as well as in sericulture. During mortuary rituals, mats have an important role functioning as shrouds. Given the rarity of such perishables in the archaeological record, the discovery of clay impressions of prehistoric matting and basketry embedded in clay matrices during the 2014 excavations of the late Neolithic-early Metal Age site of Lo Gach in southern Vietnam is noteworthy. Notwithstanding the obvious limitations inherent in the investigation of long vanished materials, this chapter discusses a recent investigation into the material and structural composition of these unique impressions, which not only informs us about early Metal Age materiality in this strategic part of Mainland Southeast Asia, but also provides insights into the level of technical knowledge and origins of the groups who made them more than 2,500 years ago. 


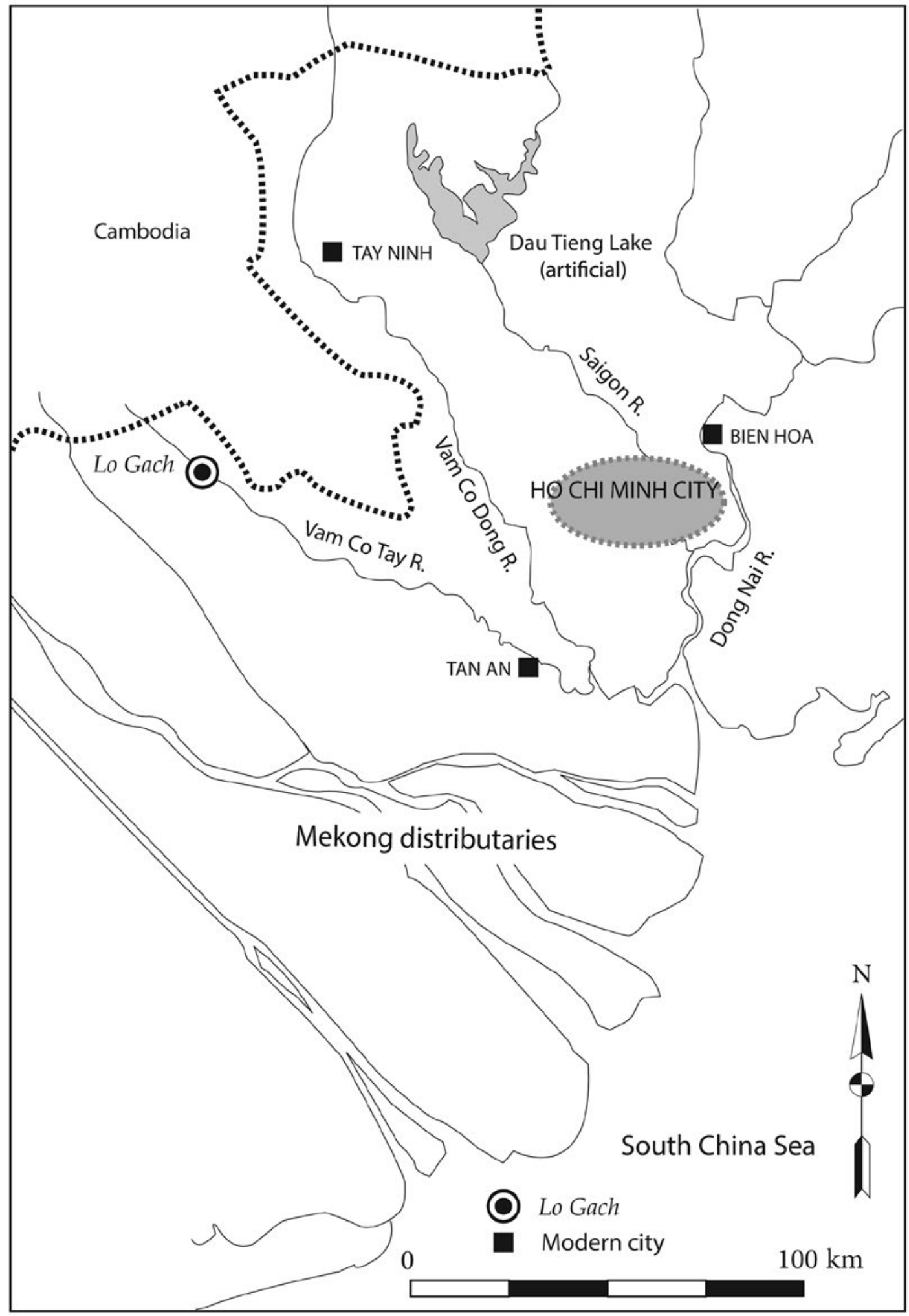

Figure 20.1 Map showing the location of the Lo Gach site.

Source: Courtesy P.j. Piper. 


\section{The site}

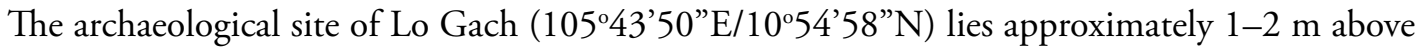
sea level on the western bank of the Vam Co Tay River in Long An Province, southern Vietnam (Figure 20.1). Although the site was first discovered in 1989, initial excavations were not carried out until 2003 when Long An Provincial Museum excavated $4 \mathrm{~m}^{2}$ of the site. In 2006, archaeologists from the Vietnam Institute of Archaeology in Hanoi returned to Lo Gach and excavated a further $24 \mathrm{~m}^{2}$. The investigators identified $0.9-1.2 \mathrm{~m}$ of cultural deposit, of which the upper $0.4 \mathrm{~m}$ contained animal bones, broken stoneware and some early elements of the Óc Eo culture. Beneath this was a complex sequence of 'grey earth mixed with fine sand' containing concentrations of pottery, animal bone and osseous artefacts. No chronometric dating was undertaken, and based on comparisons between the material culture recovered from Lo Gach, it was determined that the settlement overlapped in chronology with other Metal Age sites in southern Vietnam such as Go Ó Chua, Co Son, Go Dinh and Rach Rung, and was likely occupied between ca. 2500-2200 BP (Bui Van Liem 2008: 44). In 2012, a further test excavation by members of the Department of Archaeology in the Southern Institute for Sustainable Development in Ho Chi Minh City revealed $c a .1 .5 \mathrm{~m}$ of well stratified archaeological deposits, including floor surfaces and extensive midden deposits. Four radiocarbon dates on samples strategically located throughout the stratigraphic sequence from the basal layers up in Trenches 1 and 3 indicated an age of between 2800-2700 cal. BP (P.J. Piper, unpub. data).

Based on knowledge gained from previous excavations, a collaborative team from The Australian National University, the Southern Institute for Sustainable Development and Long An Provincial Museum decided to investigate Lo Gach in more detail in order to determine the nature of the settlement, the timing of its establishment and its likely function. Three trenches (Trenches 1-3) were excavated during April-May 2014. The largest, Trench 1, initially covering $12 \mathrm{~m}^{2}$, was placed adjacent to the 2012 test excavation. This trench was expanded in order to remove a burial partially exposed in the northeast baulk of the trench. Trenches 2 and 3 each covered $6 \mathrm{~m}^{2}$, with Trench 2 located close to the former 2006 excavations, and Trench 3 placed alongside the river where flooding has eroded away the bank exposing and destroying archaeological deposits (P.J. Piper, unpub. data). While production of a comprehensive report is still in progress, it can be said here that the excavations produced evidence for a complex sequence of well-preserved in situ floor and surface deposits that had developed and/or been deliberately laid sequentially on top of each other to produce the $1 \mathrm{~m}$ (Trench 3) to $1.5 \mathrm{~m}$ (Trenches 1 and 2) of deposit surviving at Lo Gach. More than 28 radiocarbon dates have confirmed that the Lo Gach settlement was primarily (though not exclusively) occupied between $c a$. 2800-2700 cal. BP. Many of the surfaces consisted of friable loamy sands or sands often with a hard-compacted surface. On excavation, several of these deposits were found to contain well-preserved plant impressions probably resulting from the compression of rapidly buried organic materials, including the impressions of fibre technology reported in this paper.

\section{Context}

All three excavated mat impressions were recovered from well-stratified and dated archaeological layers: Sample No. SA3-29 from Trench 3 in layer F3-5 (Figure 20.2a) has a radiocarbon date on charcoal of $2570 \pm 25$ uncal. BP or 2807-2751 cal. BP (ANU-11790; all radiocarbon dates herein were calibrated using OxCal4.2 IntCal.13; following Bronk Ramsey et al. 2010). Figure 20.2b shows sample No. SA3-33 from layer F3-6 directly below F3-5 of the same trench and sandwiched between ANU-11790 with a associated charcoal date from the underlying Context 303 of $2575 \pm 30$ or $2811-2749$ cal. BP (ANU-11792). Figure $20.2 \mathrm{c}$ shows the sample 
(SA1-70) from surface F1-32 at the northeast end of Trench 1. Layer F1-7 above F1-32 was dated on charcoal to $2560 \pm 25$ or $2805-2749$ cal. BP (78.8 per cent; ANU-11805), and layer F1-123 below the sample has an associated charcoal date of $2535 \pm 25$ or $2796-2741$ cal. BP (ANU-11802). The dating suggests that all three matting fragments were likely manufactured and utilised in the first half of the eighth century BC.

\section{Analysis}

The material and structural composition (dimensions, technique, number of elements, width of single elements, spaces, irregularities) of the impressions were measured using methodology developed for the analysis of basketry and matting by Adovasio (1977), and the results are shown in Table 20.1. However, rigidity could not be accurately measured from the impressions.

a.

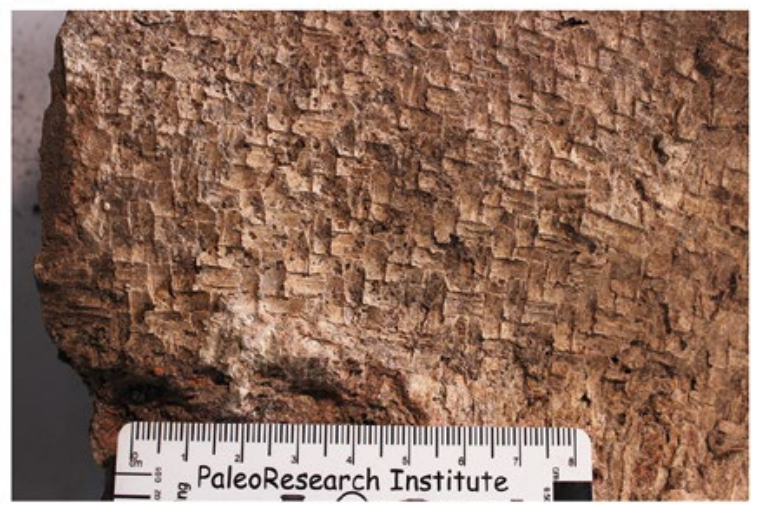

b.

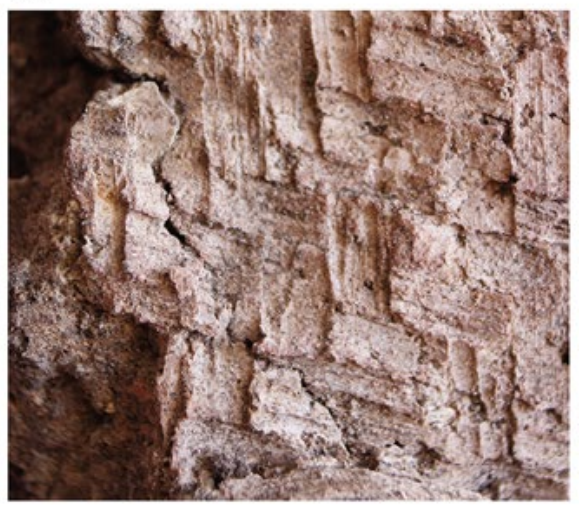

c.

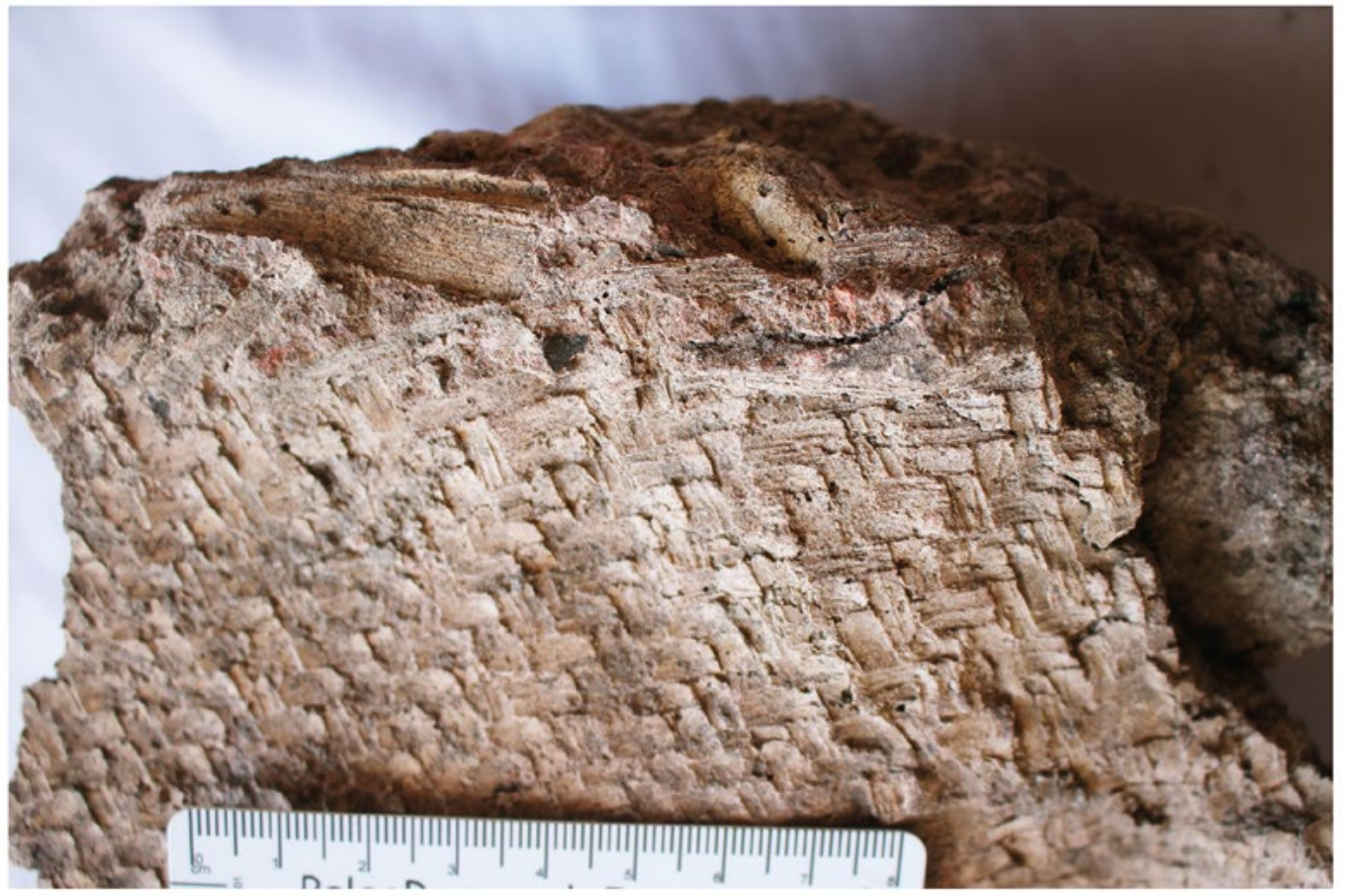

Figure 20.2 Matting impressions remaining on the clay floor surface at Lo Gach: a. Sample SA3-29; b. Sample SA3-33; c. Sample SA1-70.

Source: Photographs courtesy P.j. Piper. 
Table 20.1 Functional attributes of the Lo Gach impressions.

\begin{tabular}{|l|l|l|l|l|c|c|c|}
\hline Sample & Context & Material & Form & Technique & Elements & Angle & Size \\
\hline A3-29 & F3-5 & vegetable & matting & simple plaiting & 2 & $90^{\circ}$ & 3.75 \\
\hline SA3-33 & F3-6 & vegetable & matting & simple plaiting & 2 & $45^{\circ}$ & 3.75 \\
\hline SA-170 & F1-7 & vegetable & basketry & twill plaiting & 4 & $45^{\circ}$ & 3.75 \\
\hline
\end{tabular}

Source: J. Cameron.

\section{Material composition}

The uniform width of the basic elements in all three impressions indicates that the original matting was of vegetable origin. It would be difficult, albeit impossible, to cut animal skins into such uniform sized strips, whereas plant stems or leaves can be split lengthways uniformly (and easily) following the natural fibre bundles. The structural detail of SA1-70 is evident under moderately high magnification, and this clearly shows the material used to produce the basketry has a plant structure. Numerous fibre-producing plants are transformed into matting in Southeast Asia today, all of which require specific techniques to process. Informants have suggested that nipa palm (Nipa fruticans), which grows prolifically in estuarine habitats, could have been used to manufacture mats locally. Other botanical species traditionally employed in this region for fibre artefacts include Pandanus (Pandanaceae family). Sturdier fibres from bamboo (Poaceae family) and rattan (Arecaceae family) are most likely to have been used to make the third impression (SA 3-170). Positive identification could be obtained through phytoliths, i.e. siliceous particles formed within epidermal vegetable cells, which remain after the organic remains have disappeared, but that was beyond the scope of this research.

\section{Structural composition}

\section{Form}

The shape and size of two of the impressions on the clay floors (SA3-29 and SA3-33) suggest they are the remains of floor matting. Matting is one of the oldest forms of manually assembled fibre artefacts that is sometimes broadly classified as basketry although strictly speaking mats differ from baskets in that they are worked on a single plane, essentially two dimensional, whereas baskets are three dimensional (Figures 20.3a and 20.3b). The third sample (SA3-170) appears to be an impression of a basketry sieve tray. Figure $20.2 \mathrm{c}$ shows the artefact and fragments of the wooden frame that would have originally encircled the basket and provided the strengthening support. This type of sieve tray made from split fibre could have been used for winnowing. After harvesting, padi rice is spread onto a mat on the floor to dry. The grains are then winnowed, a process whereby padi is placed on a small flat woven tray and thrown into the air to remove the chaff while the cleaned grain falls to the back of the tray. Trays of this construction are also used in food storage, preparation and transport. 

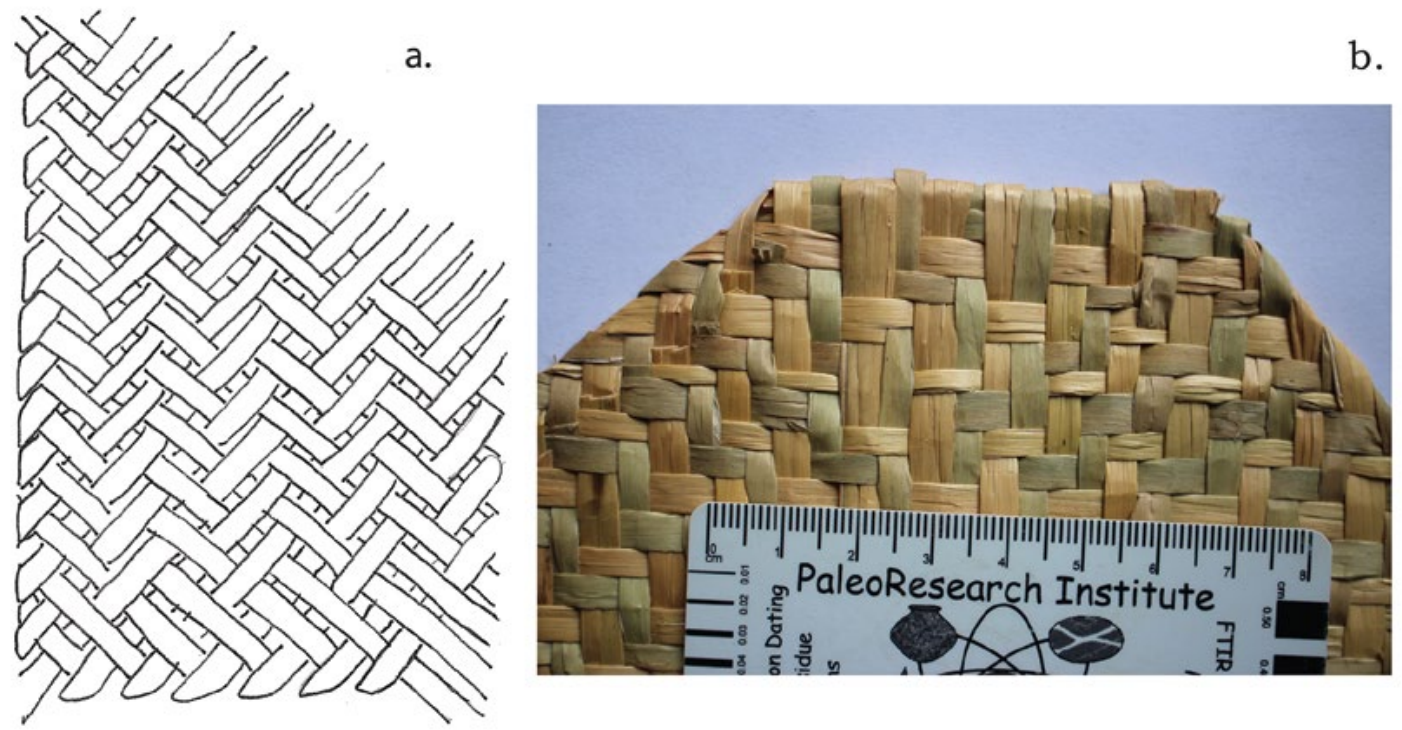

Figure 20.3 (a) Schematic diagram showing the construction of plaited matting; (b) Contemporary woven reed floor mat purchased in a market at Tan An, Long An Province in 2014.

Source: (a) J. Cameron; (b) P.J. Piper.

\section{Techniques}

Not only is matting made from stiffer fibres than those used for woven textiles, but the techniques used in construction are also different, requiring only one tool (a knife for cutting plant stems). Lengths of suitable fibres are first cut and after the shiny outer surfaces are removed, they are then rolled and stored to dry until required. The impressions remaining at Lo Gach indicate that the mats were manufactured using a technique known as plaiting, the simplest subclass of basketry in which all elements are active. Two different techniques are discernible: simple plaiting and an elaboration known as twill plaiting. Simple plaiting is evidenced in Sample SA3-29, which has single elements passing over and under each other in a 1/1 interval (Figure 20.2a, Figure 20.3). The angle of crossing of the sample was $90^{\circ}$. The second technique evidenced by sample SA3-33 is twill plaiting $(2 / 2)$ in which one set of elements passed over and under two sets in staggered intervals (Figure 20.2b, Figure 20.3). The dimensions of the elements in all samples showed a high degree of uniformity and the usage of the same basic elements. Technological continuity is also readily discernible in the ethnographic correlate obtained from Tan An market in Long An Province where mats continue to cover the common floor areas of longhouses or are used for outside seating (Figure 20.3b; P.J. Piper, personal observations, 2014). The construction of very large mats in the lower Mekong has traditionally been a co-operative exercise, constructed by groups of mat makers (usually women) seated cross-legged on the floor using both their feet and hands in the process. As no selvedges were identified in the impressions, the size of the original mats at Lo Gach was indeterminate.

The final impression under investigation belongs to a more complex basketry construction known as a winnowing tray. It is distinguished by its rigid oval hoop rim, which was possibly made from the flexible rattan (Figure 20.2c). The main section would have been plaited from softer segments of reeds or bamboo and attached to the rim. Trays of this type are usually placed on mats where their principal function is to dry food. The fibres in the impressions appear to be rigid. 


\section{Archaeological correlates}

Although both hunter-gatherers and agriculturalists made and used woven fibre mats from a wide range of locally available raw materials, as yet no archaeological fragments of matting appear to have been found at any pre-agricultural sites in Southeast Asia. Those worked plant fibres that have been unearthed from pre-agricultural sites such as Khok Phanom Di in Central Thailand (Higham and Thosarat 1987) and Gua Sireh in Borneo (Datan 1993) were the remains of bark cloth and belong to a different technological tradition that certainly is of greater antiquity in the region than matting (Cameron 2008).

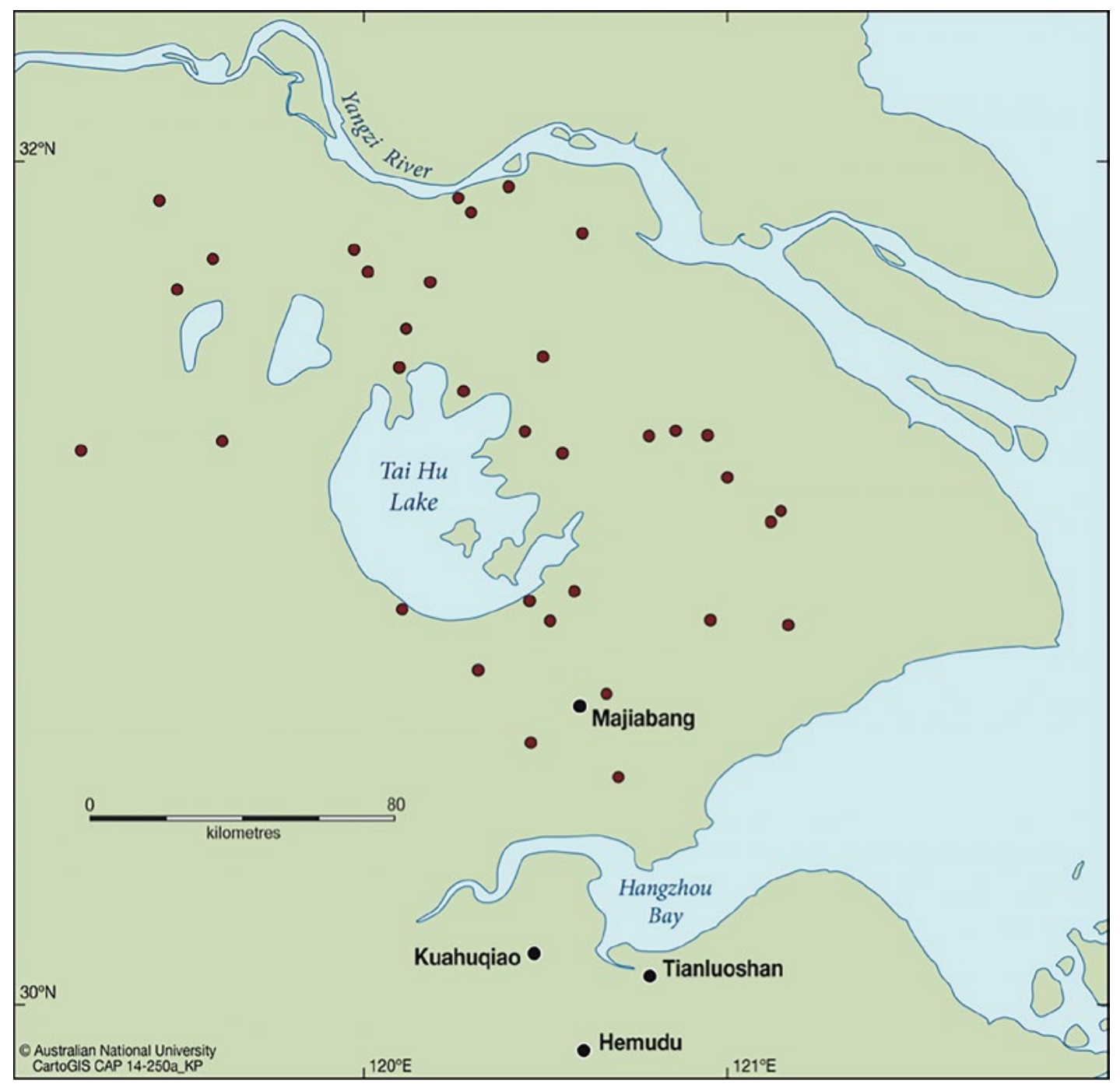

Figure 20.4 Location of Neolithic matting sites in the lower Yangzi Valley mentioned in the text. Source: J. Cameron; Base map: ANU Cartography.

The earliest firm archaeological correlates for the Lo Gach impressions come from Early Neolithic sites in the lower Yangzi Valley where matting had several distinct functions. Key matting sites are Kuahuqiao, Tianluoshan and Hemudu, all of which cluster around Hangzhou Bay in Zhejiang Province (Figure 20.4), in an area which would have been coastal when occupied. Kuahuqiao is significant in archaeology for producing extant remains of the first canoe (possibly an outrigger), found below the water table 5-6 $\mathrm{m}$ beneath the surface, preserved by waterlogging. The site also produced evidence for rice and domesticated pigs. Radiocarbon dates indicate that the site was 
occupied 8000-7000 BP (Jiang and Liu 2004). Three strips were interworked in a 3/3 basket weave construction. Since the matting was located inside the canoe, it has been suggested that it may have functioned as a sail (Jiang and Liu 2008) although many traditional canoes in this region also feature matting canopies.

Matting was also found at the early Neolithic site of Tianluoshan ( $\mathrm{Li}$ and Sun 2009) but here it performed an entirely different function to that at Kuahuqiao. Tianluoshan (ca. 8000-6800 $\mathrm{BP}$ ) is significant in prehistory for producing the earliest known evidence for rice cultivation, thereby demonstrating that early Neolithic groups in the Yangzi Valley belonging to the Hemudu culture were gradually transitioning from hunting and gathering to settled agriculture 8,000 years ago (Fuller et al. 2009). There, matting fragments were discovered at the bottom of storage pits containing fruit and nuts. The matting inserted around the walls of the pits was almost certainly intended to stop contamination with the sand, soil and gravel, providing a moisture barrier to prevent water rising up into the stored agricultural produce thereby preventing loss through fungal and bacterial contamination. This clearly demonstrates knowledge of post-harvest handling at a surprisingly early time. In modern times, for example, we know that for long-term storage of grain, moisture content in pits is not recommended to exceed 8 per cent (B. Cameron pers. comm.).

At the better-known site assigned to the eponymous Hemudu culture, archaeologists unearthed extant remains of matting structures similar to the Lo Gach impressions (Anon. 1978). The Hemudu culture is important in Southeast Asian prehistory for its possible Austronesian connections. As Chang (1989: 91) first observed, the material remains at Hemudu and later Majiabang sites are literal transcriptions of the material culture listed in linguistic reconstructions of Proto-Austronesian. At Hemudu, matting fragments were found in layer 4, dated between 7200 and $5000 \mathrm{BP}$, amidst the wooden remains of pile dwellings. The fibres were identified as Phragmites sp. (reeds) (Anon. 1978). One fragment was woven using multiple warps and wefts, in a $2 / 2$ basket weave, a technique commonly found throughout Southeast Asia for house walls, room dividers and, most importantly, flooring. Another fragment was woven using the more advanced twill technique also evidenced at Lo Gach. Twill weaves are float weaves for which a minimum of three warp groupings is essential.

Across the South China Sea, archaeological correlates have also been identified in the Niah Cave assemblages where matting was a distinguishing feature of the Neolithic/Metal Age burials in the cemetery sector and to a lesser extent at Lobang Tulang (Harrisson 1967; Barker 2013; Cameron 2016). At Niah, woven matting was identified in 48 burials of all ages and sexes. The cemetery burial matting was made using precisely the same techniques evidenced at Lo Gach, uniformly plaited in $1 / 1$ tabby weave and $2 / 2$ basket weave, but in Borneo these artefacts functioned as shrouds, alternatives to wooden coffins. One larger mat actually wrapped the exterior of a coffin, a practice also evidenced at later Dongson sites in Vietnam. While the usage of matting for flooring at Lo Gach and shrouds at Niah ostensibly seems incongruous, the two functions are not necessarily mutually exclusive. In traditional Island Southeast Asian societies, mats are multifunctional and when individuals die, deceased persons are wrapped in their sleeping mats, which then function as shrouds (Denison 1872; Cameron 2016).

To the north of Lo Gach, matting has also been found in burial contexts in many Bronze/Iron Age sites in the Red River plains of Northern Vietnam. A notable find was unearthed during the joint Australian/Vietnamese excavations of the Dongson site of Dong Xa in 2004 (Bellwood et al. 2007; Cameron 2009, 2012a, 2012b, 2012c) when a complete matting shroud woven from ramie (Boehmeria nivea) fibres was excavated. At Dong Xa, 1/1 plaited matting made from sedge was not only used to wrap the body of an adult female wearing embroidered clothing but also the wooden boat coffin itself. As mentioned above, this replicates the same mortuary practice evidenced in the cemetery sector of Niah Cave (Cameron 2016). 


\section{Conclusions}

Southeast Asian archaeologists (Bellwood 1997, 2004; Higham 1989, 2014; Higham and Lu 1998) have reconstructed the expansion of Neolithic rice farmers from South China into both Mainland and Island Southeast Asia during the fifth millennium BP. Other research (Cameron 2002, 2011, 2012a, 2012b, 2012c) into the distribution of diagnostic cloth production tools established that these Neolithic agriculturalists also had fibre-based technologies (matting, basketry and cloth production) and gradually introduced these crafts into various parts of Southeast Asia during this critical period.

Recent evidence from the above-mentioned Kuahuqiao site indicates that mat-producing agriculturalists belonging to the Hemudu culture in the lower Yangzi not only domesticated pigs and rice but also had knowledge of maritime technology, which certainly would have given them the capacity to engage in inter-regional trade during the Neolithic period. Elsewhere, I (Cameron 2002, 2011, 2015) have argued that the invention of textile technology in the lower Yangzi would have provided a catalyst for the development of exchange networks that preceded the famous Maritime Silk Road of the historical period.

It is possible that the weaving technologies observed at Lo Gach, a sedentary settlement site dating to $c a$. 2800-2700 cal. BP, was first introduced to Southern Vietnam during the foragerfarming transitions about 4000 BP. For example, spinning tools have been identified at An Son (Cameron 2002) and Rach Nui (Piper and Oxenham 2014; Oxenham et al. 2015), two of the earliest agricultural settlement sites in the region, as well as historical sites belonging to the Funan culture (Cameron 2002).

Elsewhere in Vietnam, firm evidence for cloth production introduced with agriculture from South China dates from the terminal Neolithic at sites assigned to the Phung Nguyen culture and continues through the Bronze and Iron Age at sites assigned to the Dong Dau, Go Mun and Dongson cultures, extending to central and southern coastal Vietnam at Proto-Historic sites assigned to the Sa Huynh culture.

Undoubtedly, the matting impressions from Lo Gach indicate that the groups who occupied the site were thoroughly familiar with plant fibres and the simple plaiting techniques used by agriculturalists to obtain the exigencies of daily life. While such heavy-duty, mundane artefacts, quickly made and discarded when worn out, are not generally afforded much attention in archaeology, they provide insights into pre-Funan material culture. At the broadest level, the data indicate levels of social and technological complexity. More specifically, the matting impressions elucidate the fundamental role of fibre artefacts in agricultural households occupying the flat deltaic terrain of the Mekong Delta and provide additional links to agricultural households who initially developed agriculture in South China.

\section{Acknowledgements}

Thanks are due to Philip J. Piper who recorded the impressions in situ and kindly provided the background information on the site.

\section{References}

Adovasio, J.M. 1977. Basketry Technology. Chicago: Aldine Publishing Company.

Anon. 1978. First season's excavations of Ho-mu-tu (Hemudu) in Yu-Yao County, Chekiang (Zhejiang) Province. Khao Ku Hsueh Pao (Kao Gu Xue Bao) 1: 39-94 (in Chinese). 
1991. A preliminary report on the excavation of the site of Keqiutou Pingtan, Fujian. Kaogu Xuebao: 587-589.

Barker, G. (ed.). 2013. Rainforest Foraging and Farming in Island Southeast Asia, The archaeology of the Niah Caves, Sarawak, vol. 1. Cambridge: McDonald Institute for Archaeological Research.

Bellwood, P. 2004. The origins and dispersals of agricultural communities in Southeast Asia. In I. Glover and P. Bellwood (eds), Southeast Asia: from Prehistory to History, pp. 21-40. London: RoutledgeCurzon.

- 1997. Prehistory of the Indo-Malaysian Archipelago. Revised edition. Honolulu: University of Hawaii Press.

—. 1985. Prehistory of the Indo-Malaysian Archipelago. North Ryde: Academic Press.

Bellwood, P. and J. Cameron, Nguyen Van Viet, Bui Van Liem. 2007. Ancient boats, boat timbers, and locked mortise-and-tenon joints from Bronze/Iron-Age Northern Vietnam. International Journal of Nautical Archaeology 36: 2-20. doi.org/10.1111/j.1095-9270.2006.00128.x.

Bronk Ramsey, C., M. Dee, S. Lee, T. Nakagawa and R. Staff. 2010. Developments in the calibration and modeling of radiocarbon dates. Radiocarbon 52(3): 953-961. doi.org/10.1017/ S0033822200046063.

Bui Van Liem. 2008. Di Chi Lo Gach (Long An), Khao Co Hoc 2008(2): 26-44 (in Vietnamese).

Cameron, J. 2002. Textile Technology in the Prehistory of Southeast Asia. Unpublished PhD thesis, The Australian National University, Canberra.

- 2008. Trans-oceanic transfer of bark-cloth technology from South China-Southeast Asia to Mesoamerica? In G. Clark, F. Leach and S. O'Connor (eds), Islands of Inquiry: Colonisation, Seafaring and the Archaeology of Maritime Landscapes, pp. 203-210. Terra Australis 29. Canberra: ANU E Press.

- 2011. Textile crafts in the Gulf of Tongking. The intersection between archaeology and history. In N. Cooke, T. Li and J.A. Anderson (ed.), The Tongking Gulf through History, pp. 25-38. Philadelphia: University of Pennsylvania Press.

- 2012a. Leonard Aurousseau's hypothesis revisited: the intersection between history and archaeology. In M.L. Tjoa-Bonatz, A. Reinecke and D. Bonatz (eds), Crossing Borders: Selected Papers from the 13th International Conference of Southeast Asian Archaeologists, vol. 1, pp. 221-229. Singapore: NUS Press.

2012b. The spinning tools. In C.F.W. Higham and A. Kijngam (eds), The Origins of the Civilization of Angkor. vol. V. The Excavation of Ban Non Wat: Part Three. The Bronze Age, pp. 497504. Bangkok: Fine Arts Department.

- 2012c. The spinning tools. In C.F.W. and A. Kijngam (eds), The Origins of the Civilization of Angkor. vol. VI. The Excavation of Ban Non Wat: The Iron Age, Summary and Conclusions, pp. 115119. Bangkok: Fine Arts Department.

2015. A Prehistoric Maritime Silk Road: Merchants, Boats, Cloth and Jade. In Beyond the Silk Road: Asian Maritime History and Culture. The Collection of Papers for the 6th Session of Academic Forum (English Papers). August 2015. Shanghai: China Maritime Museum, pp. 58-69. 
2016. The Archaeological Textiles from the Great Cave at Niah: Analysis and Technical Implications. In Graeme Barker (ed.), Rainforest Foraging and Farming in Island Southeast Asia, The Archaeology of the Niah Caves, Sarawak, vol. 2, pp. 345-362. Cambridge: McDonald Institute of Archaeological Research.

Cameron, J., P. Bellwood, Bui Van Liem, Nguyen Van Viet. 2009. Kêt Qua Nghiên Cuu Vai Trong Van Hoa Dông Son Tai Di Tich Dông Xa (Hung Yên) Trong Hop Tac Khoa Hoc Viêt Nam-Uc Lân Thu Nhât. Khao Co Hoc 2: 20-25 (in Vietnamese).

Chang, K.-C. 1989. Taiwan archaeology in Pacific perspectives. In K.-C. Chang, K-C. Li, A.P. Wolf and A. Yin (eds), Anthropological Studies of the Taiwan Area: Accomplishments and Prospects, pp. 87-98. Taipei: National Taiwan University.

Datan I. 1993. Archaeological Excavations at Gua Sireh, Serian, and Lubang Angin, Gunung Mulu National Park, Sarawak, Malaysia. Special Monograph no. 6. Kuching: Sarawak Museum.

Denison, N. 1872. Journal (from 29th April to 25th May, 1872) when on a trip from Sarawak to Meri, on the north-west coast of Borneo in the Brunei territory. Manuscript, National Library of Australia.

Fuller, D.Q., Q. Ling, E.L. Harvey. 2009. An evolutionary model for Chinese rice domestication: reassessing the data of the Lower Yangtze region. In S.-M. Ahn and J.-J. Lee (eds), New Approaches to Prehistoric Agriculture, pp. 313-345 Seoul: Sahoi Pyoungnon.

Harrisson, B. 1967. A classification of stone-age burials from Niah Great Cave, Sarawak. Sarawak Museum Journal 15: 126-155.

Higham, C.F.W. 1989. The Archaeology of Mainland Southeast Asia. Cambridge: Cambridge University Press.

Higham, C. 2014. Early Mainland Southeast Asia: From First Humans to Angkor. Bangkok: River Books.

Higham, C. and T.L.-D. Lu. 1998. The origins and dispersal of rice cultivation. Antiquity 72 (278): 867-877. doi.org/10.1017/S0003598X00087500.

Higham, C.F.W. and R. Thosarat (eds). 1987. The Excavation of Khok Phanom Di. vol. III (part I). The Material Culture. London: Society of Antiquaries.

Leping Jiang and Li Liu. 2005. The discovery of an 8000-year-old dugout canoe at Kuahuqiao in the Lower Yangzi River, China. Antiquity 79 (305) September: Project Gallery.

Li Anjun and Sun Guoping. 2009. Tianluoshan Site, a new window of Hemudu Culture. Hangzhou: Xiling Seal Society Publishing House, Hangzhou (in Chinese).

Oxenham, M.F., P.J. Piper, P. Bellwood, C. Ho. Bui, K.T.K. Nguyen, Q.M. Nguyen, F. Campos, C. Castillo, R. Wood, C. Sarjeant, N. Amano, A. Willis and J. Ceron. 2015. Emergence and diversification of the Neolithic in Southern Vietnam: insights from coastal Rach Nui. The Journal of Island and Coastal Archaeology 10(3): 1-30. doi.org/10.1080/15564894.2014.980473.

Piper P.J. and M.F. Oxenham. 2014. Of prehistoric pioneers: the establishment of the first sedentary settlements in the Mekong Delta region of Southern Vietnam during the period 2000-1500 cal. BC. In K. Boyle, R.J. Rabett and C.O. Hunt (eds), Living in the Landscape: Essays in Honour of Graeme Barker, pp. 209-226. Cambridge: McDonald Institute of Archaeological Research. 
This text is taken from New Perspectives in Southeast Asian and Pacific Prehistory, edited by Philip J. Piper, Hirofumi Matsumura and David Bulbeck, published 2017 by ANU Press, The Australian National University, Canberra, Australia. 